Received: 19 October 2020 Accepted: 26 October 2020

Keywords: Holocaust; Jews; Theresienstadt; Dresden; Deportation; Nazis

\section{The Fate of 435 Jewish Individuals Deported from Dresden to Theresienstadt between 1942 and 1944.}

\author{
By Des Maguire
}

Abstract: Making Germany Judenfrei (free of Jews) or Judenrein (purified of Jews) was one of the pillars of the National Socialist (Nazi) Party in Germany. One means of achieving this from 1941 onwards was the deportation of Jewish people to ghettoes or death camps in the occupied territories, primarily Poland, but also including Bohemia (now in the Czech Republic) where the Theresienstadt Ghetto was located.

As part of this criminal act, 435, mainly elderly Jews were deported from Dresden to the Theresienstadt from 1942 to 1944. Using the personal information shown on the Gestapo deportation lists, this study shows that new facts about the fate of these people can emerge when the information provided is analysed on a group basis. It can also corroborate information provided elsewhere. For example, the extremely high death rate $(87 \%)$ suffered by these people from Dresden echoes the overall death rate of $84 \%$ given by Yad Vashem for the 118,000 unfortunate individuals who were in the Ghetto and either perished there or perished elsewhere ${ }^{1}$. This demonstrates that a close analysis of one group of people can reveal corroborative knowledge about the Holocaust, and can provide starting point for comparative studies of the experiences of other deportees in different locations.

\title{
Introduction
}

There have been a plethora of books and academic articles written about the Nazi period in Germany (1933-1945), and the catastrophic, and often murderous effects the Nazis had upon European Jewry. It may therefore appear superfluous to add yet another article to the pile. However, this article exploits new material made available by the opening up of the International Tracing Service's (ITS) massive documentary archive at Bad Arolsen in 2007 after years of pressure on the managing agency, the International Committee of the Red Cross, to do so. Digital copies of the database were made available to institutions in the member countries ${ }^{2}$.

Drawing on the London based Wiener Holocaust Library's copy of the ITS database, this article focuses on a very small part of that archive, namely, the 10 Gestapo deportation lists $(\mathrm{V} / 1$ - V/10) containing the names of the 435 mostly elderly Jews who were deported the 113 kilometres from Dresden to the Theresienstadt Ghetto in the period July 1942 to December 1944. These deportations were an intrinsic part of the Nazi ideology to make Germany Judenfrei (free of Jews) or Judenrein (purified of Jews). As will be shown in this article, a name on a deportation list was akin to a death sentence. This, of course, was the intention of the Nazis after the Wannsee Conference of 20 January 1942. As Jah notes $(2016)^{3}$, the deportation of Jews was carried out for one purpose: whether it was death by murder in the gas chambers, death by over-work in the slave labour camps, or death by starvation and disease in the ghettoes, that goal was the extinction of European Jewry.

In this murderous system, the Theresienstadt Ghetto functioned as a smokescreen for the real intentions of the Nazis ${ }^{4}$. It was presented as a spa town with many facilities where elderly Jews could retire in safety ${ }^{5}$. As the fate of the Jews from Dresden in the article will show nothing was further from the truth, but this myth enabled the Nazis to 'sell' to younger Jews their deportation to the east as work assignments ${ }^{6}$. This illusion was even extended to the visit of the International Red Cross (IRC). Prior to the visit on June 23 1944, the ghetto was beautified, but as

( 2020 The Author(s). This is an open access article distributed under the terms of the Creative Commons Attribution License (http://creativecommons.org/ licenses/by/4.0/) 
an eye-witness points out, this beautification was very limited. The barracks were painted only on the street side; the rooms which could be seen from outside were put in order; and in the psychiatric unit the nurses had to put flowers on the ${ }^{7}$. All this came at the cost of 7,503 individuals who were deported from Theresienstadt to Auschwitz between May 16 and May 181944 , in order to reduce the overcrowding there ${ }^{8}$.

In the wake of this visit, the Nazis made a propaganda film to demonstrate their benevolent attitude towards the Jews and to dispel the rumours about the death camps. However, after the film was made, most of the actors in the film and most of the children in the ghetto, were sent to the gas chambers of Auschwitz-Birkenau?

The purpose of this article is to show that a close analysis of a group of Jews of roughly the same age, from the same location, going to the same destination and sharing the same fate, can reveal new knowledge about the Holocaust, and can provide a starting point for comparative studies with the experiences of Jews deported from other German and Austrian cities. The evidence presented will also act to dispel the Nazi myth about Theresienstadt being a cosy retirement complex.

\section{Main Findings}

\section{Deportation summary}

The Wannsee Conference, which converted the ideological desire of the Nazis for a Judenfrei Germany into public policy ${ }^{10}$, took place on the 20 January 1942, and the first manifestation of the systematic approach to deporting Jews from Dresden occurred on the 01 July 1942 ; deportations continued regularly thereafter.

There were 10 deportations from Dresden to Theresienstadt over the period 01 July 1942 to 08 December 1944 numbered from V/1 to V/10. However, V/10 consisted of one main action on 11 January 1944 and six smaller actions involving only one individual. Table 1 summarising all the deportations is given below.

Table 1. Deportations to Theresienstadt from Dresden.

\begin{tabular}{|c|c|c|c|c|c|c|}
\hline \multirow[b]{2}{*}{ TransportationNo. } & \multirow[b]{2}{*}{ Date } & \multicolumn{2}{|c|}{ Survived } & \multicolumn{2}{|c|}{ Perished } & \multirow[b]{2}{*}{ Total } \\
\hline & & Male & Female & Male & Female & \\
\hline $\mathrm{V} / 1$ & $01 / 07 / 1942$ & 0 & 0 & 15 & 35 & 50 \\
\hline$V / 2$ & 14/07/1942 & 0 & 4 & 6 & 40 & 50 \\
\hline$V / 3$ & $28 / 07 / 1942$ & 3 & 3 & 23 & 21 & 50 \\
\hline$V / 4$ & 11/08/1942 & 0 & 0 & 10 & 40 & 50 \\
\hline $\mathrm{V} / 5$ & $25 / 08 / 1942$ & 1 & 2 & 16 & 31 & 50 \\
\hline$V / 6$ & 07/09/1942 & 0 & 2 & 11 & 37 & 50 \\
\hline $\mathrm{V} / 8$ & $29 / 03 / 1943$ & 4 & 5 & 11 & 12 & 32 \\
\hline$V / 9$ & $21 / 06 / 1943$ & 0 & 3 & 11 & 14 & 28 \\
\hline $\mathrm{V} / 10$ & $11 / 01 / 1944$ & 3 & 21 & 8 & 10 & 42 \\
\hline$V / 10$ & $09 / 02 / 1944$ & 0 & 0 & 0 & 1 & 1 \\
\hline$V / 10$ & 08/03/1944 & 0 & 0 & 1 & 0 & 1 \\
\hline $\mathrm{V} / 10$ & 09/08/1944 & 0 & 0 & 0 & 1 & 1 \\
\hline$V / 10$ & $30 / 08 / 1944$ & 0 & 1 & 0 & 0 & 1 \\
\hline$V / 10$ & $29 / 09 / 1944$ & 0 & 1 & 0 & 0 & 1 \\
\hline Total & & 13 & 43 & 121 & 258 & 435 \\
\hline
\end{tabular}

\section{NUMBERS}

Those Jews, who were selected for deportation to Theresienstadt, were chosen primarily on the basis of the criteria set out in the Wannsee Conference of January 1942. These were ${ }^{11}$ :

- Aged 65 or over.

- A partner of a Jew aged 65 or over, if that partner is Jewish and not Aryan.

- Aged 55 or over if sick. 
Specific facts emerge from this table.

- More than twice as many women as men were deported.

- The death rate of $87 \%$ of all those deported was extraordinarily high.

- That the Germans were still deporting Jews to the East in late 1944 when it was obvious that the war was lost. Although these deportations consisted of individual persons whose Aryan partner had either died or divorced them ${ }^{12}$.

- There was a decrease in numbers deported between $\mathrm{V} / 6$ and $\mathrm{V} / 9$, only for those numbers to increase again with $\mathrm{V} / 10$.

Another fact revealed by the information in Table 1 is that the deportations continued until the end of 1944 even when the war was effectively lost. This persistence is demonstrated by the fact that a further deportation, V/11, was planned for the 15 February 1945 . There were 56 individuals earmarked for this deportation. This deportation did not occur because of the bombing of Dresden on the night of 13/14 of February which destroyed much of the city's infrastructure and the Gestapo headquarters ${ }^{13}$. The fact that the deportations continued confirms the view put forward by Longerich $(1994)^{14}$ and Held $(2008)^{15}$, already mentioned in the Introduction, that 'purifying' the German race by expelling all others was a fundamental tenet of Nazism and not subordinate to waging a war. Urban (2013) summarises the climate prevailing for the Jews at that time, writing: "The ideology of race and the fervour with which the 'final solution of the Jewish question' was developed and then pursued always won the upper hand over rational requirements." ${ }^{16}$

The final observation revealed in Table 1 is that there were fewer people deported on transports V/6, V/7, V/8 and V/9, only for the numbers to increase again with transport $\mathrm{V} / 10$. The reason there were fewer people on V/6, V/7, V/8 and V/9 is that there were fewer Jews in Dresden to whom the Wannsee criteria applied than for the previous 5 deportations. This is obliquely confirmed in Turner's (1999) article on Victor Klemperer when he writes that Klemperer's friends had disappeared because the deportation of most of Dresden's Jews had taken place in 1942 and $1943^{17}$.

The increase in numbers occurred again with transport V/10 because the criteria for selection for Theresienstadt established at Wannsee in January 1942 were changed by the head of the Gestapo, Heinrich Müller, on 18 December $1943^{18}$. He ordered that Jews who had been married to non-Jews, but who were divorced or whose spouse had died were to be deported to Theresienstadt. However, the situation was so delicate, that Müller had to wait to implement his decision ${ }^{19}$. The list for deportation V/10 confirms the change in Theresienstadt selection criteria as there are two additional columns on it: 'St. A' (Staatsangehörigkeit/nationality) and 'Stand' (marital status). These are shown in Figure 1.

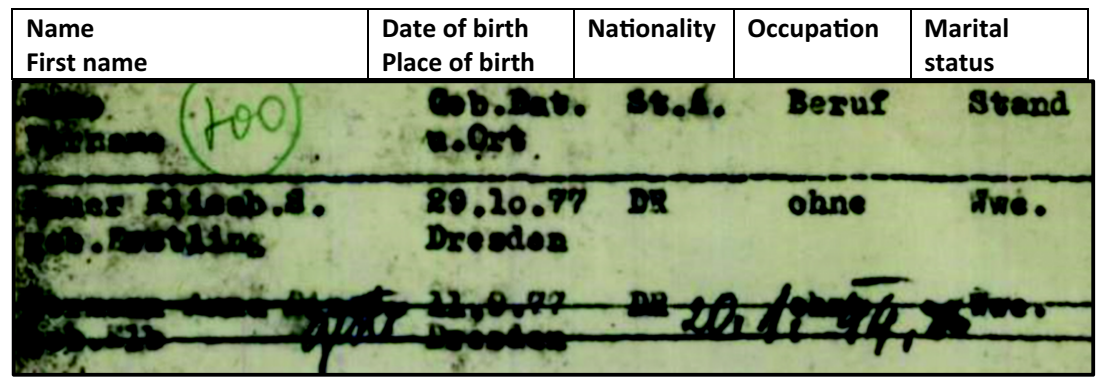

Figure 1. V/10 deportation list ${ }^{1}$.

For both Elizabeth Bauer and Anna Bormann, whose details are shown on the V/10 deportation list, the nationality is given as DR (Deutsches Reich), so they had German nationality, whilst their marital status is recorded as Wwe (Witwe) or widowed. These two additional columns were not required on previous deportations because the victims were not protected by marriage to non-Jews and all Jews had their German citizenship withdrawn from them on 25 November $1941^{20}$.

The fact that the Nazi authorities in Dresden were deporting Jewish spouses, whose partner had either died or divorced them, taken with the knowledge that they were planning deportation V/11 on the 15 February 1945 to include all Mischlinge (those with mixed Jewish/Aryan ancestry) in that city, are additional examples that the Nazis in Dresden were so fanatically anti-Semitic that ideology always took precedence over the needs of war and being pragmatic ${ }^{21}$.

High Death Rate

An explanation for some of these facts lies in what was decided at Wannsee. 
Table 2, which gives per deportation the number of those that survived and those that perished, confirms the high death rate of $87 \%$.

Table 2. Number of deportees who survived and number who perished.

\begin{tabular}{|c|c|c|c|c|c|c|c|}
\hline Dep.No. & Dep.Date & NumberSurvived & NumberPerished & & Where Peri & & \\
\hline & & & & Theresienstadt & Auschwitz & Treblinka & Other \\
\hline $\mathrm{V} / 1$ & 01/07/1942 & 0 & 50 & 42 & 8 & 0 & 0 \\
\hline$V / 2$ & $14 / 07 / 1942$ & 4 & 46 & 44 & 2 & 0 & 0 \\
\hline$V / 3$ & 28/07/1942 & 6 & 44 & 20 & 24 & 0 & 0 \\
\hline$V / 4$ & $11 / 08 / 1942$ & 0 & 50 & 42 & 7 & 0 & 1 \\
\hline$V / 5$ & $25 / 08 / 1942$ & 3 & 47 & 41 & 4 & 2 & 0 \\
\hline V/6 & 07/09/1942 & 2 & 48 & 40 & 8 & 0 & 0 \\
\hline $\mathrm{V} / 7$ & 22/09/1942 & 3 & 24 & 13 & 11 & 0 & 0 \\
\hline $\mathrm{V} / 8$ & 29/03/1943 & 9 & 23 & 15 & 8 & 0 & 0 \\
\hline $\mathrm{V} / 9$ & $21 / 06 / 1943$ & 3 & 25 & 9 & 16 & 0 & 0 \\
\hline $\mathrm{V} / 10$ & $11 / 01 / 1944$ & 24 & 18 & 11 & 6 & 0 & 1 \\
\hline $\mathrm{V} / 10$ & 09/02/1944 & 0 & 1 & 1 & 0 & 0 & 0 \\
\hline $\mathrm{V} / 10$ & 08/03/1944 & 0 & 1 & 0 & 1 & 0 & 0 \\
\hline $\mathrm{V} / 10$ & 09/08/1944 & 0 & 1 & 1 & 0 & 0 & 0 \\
\hline $\mathrm{V} / 10$ & 30/08/1944 & 1 & 0 & 0 & 0 & 0 & 0 \\
\hline $\mathrm{V} / 10$ & 29/09/1944 & 1 & 0 & 0 & 0 & 0 & 0 \\
\hline $\mathrm{V} / 10$ & 08/12/1944 & 0 & 1 & 1 & 0 & 0 & 0 \\
\hline Total & & 56 & 379 & 280 & 95 & 2 & 2 \\
\hline
\end{tabular}

However, this table also shows that around $64 \%$ of those who were deported from Dresden actually perished in the Ghetto whereas according to Yad Vashem's figures, overall, only $28 \%$ of those who were in Theresienstadt actually perished there. The bulk, 85,000 , died elsewhere ${ }^{22}$, so for the majority, the Ghetto was a transit camp.

A possible explanation for this difference could be the age of those deported from Dresden. Figure 2, shows that most of those Jews deported from Dresden to Theresienstadt fulfilled the criteria established at the Wannsee Conference as 324 individuals were 65 or over.

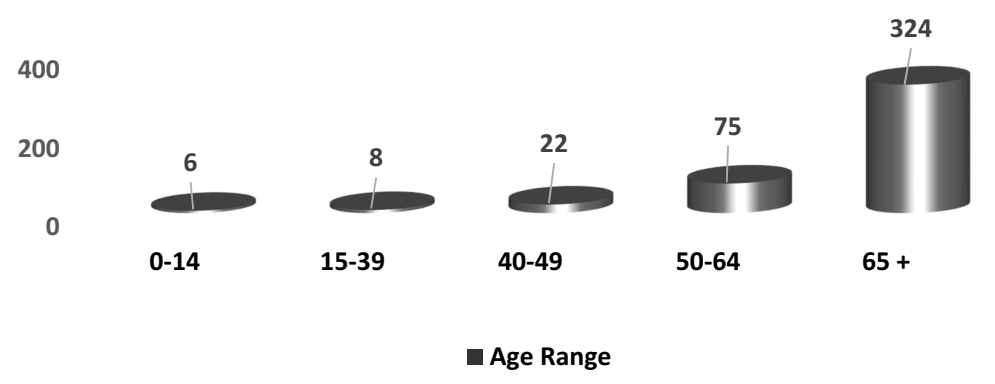

Figure 2. Dresden deportees by grouped by age range.

Yet the age of the deportees from Dresden only gives a partial explanation for the high death rate amongst that cadre. Two other facts are also relevant: the systematic persecution of the Jews in Dresden prior to their deportation, and the conditions in Theresienstadt.

Statements from survivors who were in Dresden at the time reveal that Jews were forbidden to buy meat, fish, chicken and cooking oils ${ }^{23}$, and what they did have was stolen from them by the Gestapo ${ }^{24}$. The situation was similar in Berlin, for as the newspaper article below (Figure 2 ) shows, food, tobacco and money were taken from the Jewish inhabitants there by the police. 


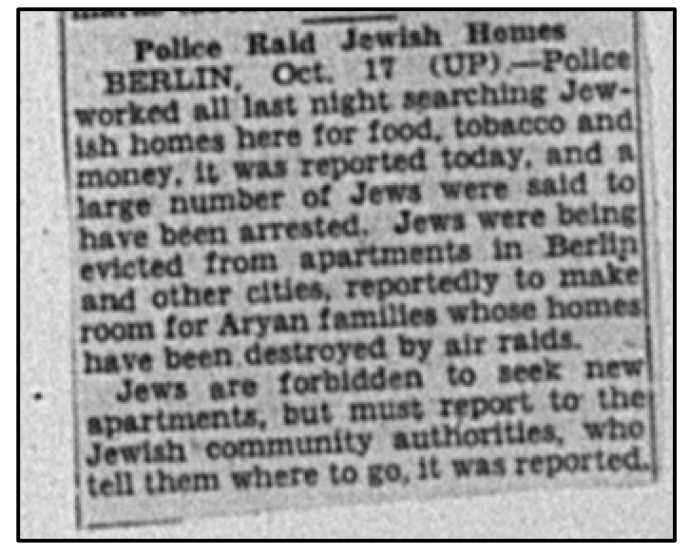

Figure 3. Jewish persecution in Berlin².

The consequence of this was that the deportees were most likely weakened before they went to Theresienstadt. In addition, Theresienstadt was a small town built to accommodate 5,000 , but which had 60,000 people crammed into it ${ }^{25}$ by the Germans. As a result, the hygiene conditions were disastrous. The crowding, together with the poor food, led to periodic epidemics of diphtheria, typhus, dysentery and suicides $^{26}$. This is a conclusion which Jah (2016) comes to when he writes: "Many died only a few weeks after deportation to Theresienstadt because of the catastrophic conditions in the ghetto" ${ }^{27}$. An eyewitness statement from Hans Walter Hirschberg confirms this: "Virtually all the old people and those amongst the young who were not selected for work, starved."28

A further analysis of the deportations lists of Jews from Dresden to Theresienstadt was carried out covering the following characteristics: gender, survival by deportation date, places of birth and places of death, and occupations and houses for Jews. The results are presented in the tables that follow.

\section{Gender}

When looked at from a gender perspective, the results show subtle differences in the survival and death rates between men and women. A summary table below (Table 3) reveals the following:

Table 3. Death and survival rates by gender.

\begin{tabular}{lcc}
\hline & Male Total & Female Total \\
\hline Number of Deportees & 134 & 301 \\
Number Perished & 121 & 258 \\
Number Survived & 13 & 43 \\
\hline
\end{tabular}

When the survival rates of men and women are expressed in percentage terms and the average age of male and female deportees is considered as in Table 4,

Table 4. Survival rates by gender and average age.

\begin{tabular}{lllll}
\hline & \multicolumn{2}{c}{ Survived } & \multicolumn{2}{c}{ Perished } \\
\hline Number & Male & Female & Male & Female \\
$\%$ & 13 & 43 & 121 & 258 \\
Average Age (years) & $9.7 \%$ & $14.3 \%$ & $90.3 \%$ & $85.7 \%$ \\
\hline
\end{tabular}

Then:

- Of the 301 female deportees, 43 or $14.3 \%$ survived and they had an average age of 63.1 years.

- Whilst of the 134 male deportees, only 13 or $9.7 \%$ survived and they had an average age of 62.3 years. 
So, in terms of survival, proportionately more women than men survived and those women who survived were slightly older on average than the male survivors.

The proportionately higher survival rate for women is not statistically significant without statistics for all the Theresienstadt survivors split by gender. However, it may be that a more nuanced approach needs to be taken regarding Holocaust survival and gender. The accepted notion is that more men than women survived because men were better equipped to endure the rigours of forced labour and because mothers went with their children into the gas chambers ${ }^{29}$, but as Theresienstadt was envisaged as a ghetto for elderly Jews, the situation with children did not often arise. As shown in Figure 1 only six individuals of the group studied were under 14. Hajkova (2016) asserts that Theresienstadt was "gender-wise, a man's world", and that if women had a role at all, it was in "supporting, affirming and in social roles"30. However, as the experience of the Dresden deportees shows, Theresienstadt may have been 'a man's world', but that did not guarantee that men lived longer than women there as neither men nor women 65 or over were required to work $^{31}$.

\section{Survival by deportation date}

Figure 4 shows the percentage of survivors per deportation and indicates that deportations V/8, 19 March 1943, and deportation V/10, 11 January 1944, were the exceptions in terms of survival rate. For all the other deportations, if there were any survivors at all, then only between four and twelve per cent survived.

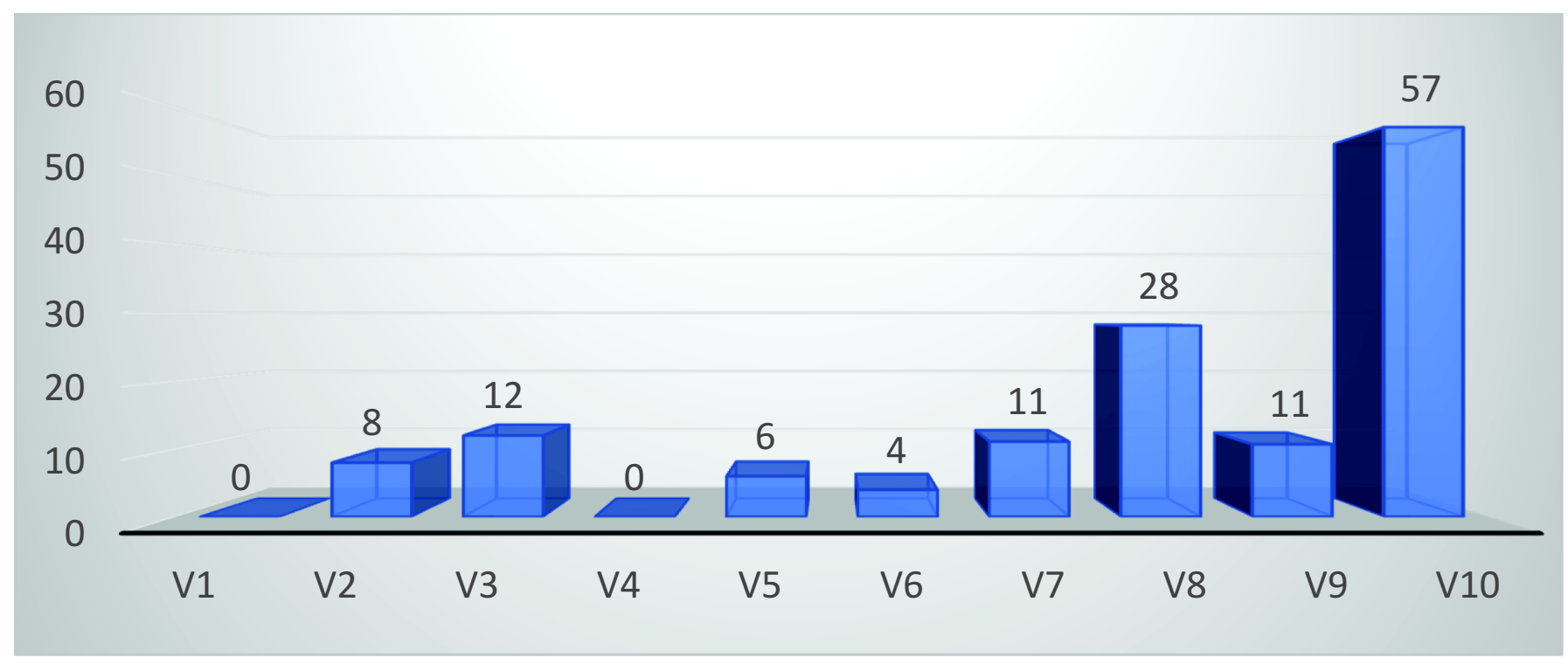

Figure 4. Survivors per deportation (\%).

The curiosity in Figure 4 is the low survival rate for deportation V/9, 21 June 1943, because deportations V/8, V/9 and the deportations comprising V/10 all took place in 1943 and 1944. As Goldenbogen (1996) ${ }^{32}$ points out, in Dresden, those who were the oldest went first. Comparing the profile of those on deportations V/8 and V/9 in Table 5, what is striking is that while the average age of the survivors from both deportations is the same, those who were deported on V/9 21 June 1943 were considerably younger on average than those deported on 29 March 1943.

Table 5. Deportations V/8 and V/9 age comparison.

\begin{tabular}{llcc}
\hline Deportation & Date & Average age at deportation of all deportees (years) & Average age at deportation of survivors (years) \\
\hline V/8 & $29 / 03 / 1943$ & 62.75 & 55 \\
V/9 & $21 / 06 / 1943$ & 53.25 & 55 \\
\hline
\end{tabular}

A possible explanation for the high death rate lies in the composition of deportation V/9. It was the last deportation of Jews from Dresden before the deportation of those in mixed marriages who were divorced or their partner had died. V/9 contained all the members of the Jewish administration in Dresden who were responsible for Jewish life there, for producing the lists of those who were to be deported and for looking after the sick and the weak ${ }^{33}$. All of them, including their children, were deported to Theresienstadt on 21 June $1943^{34}$. The deportation list for 
V/9 $9^{35}$ includes the name of Dr. Kurt Hirschel, who was the leader of the Jewish community in Dresden, and his wife and two sons. A year later, on 28 October 1944, they were sent to Auschwitz-Birkenau and perished there. There were two other young children on deportation V/9. All these children lowered the average age of those sent to Theresienstadt and all perished in Auschwitz-Birkenau. If the ages of the 4 children are excluded then the average age at deportation on V/9 rises to 60.62 years.

According to Hajkova ${ }^{36}$, there was a codex at Theresienstadt which included a 'family rule'. If one member was selected for deportation from Theresienstadt, then all family members went on the same transport. This is what occurred with the Hirschels who were all transported from Theresienstadt to Auschwitz-Birkenau on transport "Ev", 28 October $1944^{37}$. For this reason, the fact that there were children and family groups on deportation V/9 partly explains its relatively higher death rate in comparison with deportation V/8. In addition, it shows that using an 'average' as a figure for comparison can hide a lot of individual differences.

The relatively higher survival rate on the $\mathrm{V} / 10$ deportations is easier to explain. The victims were in Theresienstadt for a shorter period. The food there improved with the inclusion of fresh vegetables from summer 1944 onwards ${ }^{38}$, and they ate better rations prior to their deportation whilst their non-Jewish spouses were alive because Aryans were not subject to the same food restrictions as Jews. The survival rate of those who were part of the V/10 deportations appears to support Gerlach's $(1998,)^{39}$ contention that "The majority of ... Jewish partners in 'mixed marriages' were thus able to survive the war ...".

\section{Places of birth and places of death}

The deportation lists also contain the place of birth for everyone. This is useful for family origin and for revealing migration movements in Central Europe, but also for indicating nationality. The Nürnberg race laws of 1935 made German Jews second class citizens ${ }^{40}$ and German citizenship was withdrawn completely from them in 1941 when they became stateless ${ }^{41}$.

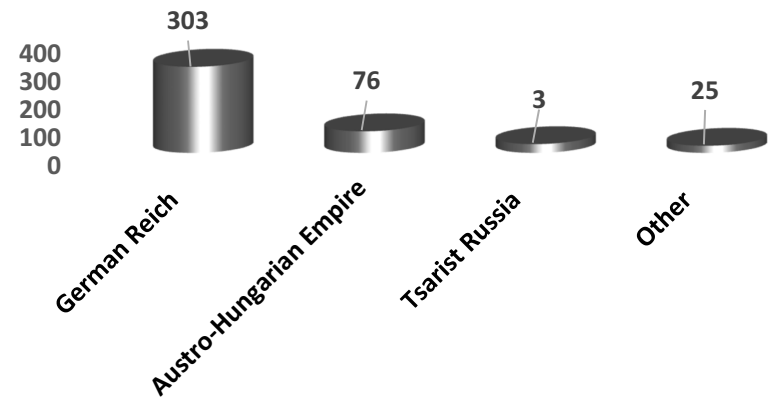

Figure 5. Places of birth.

Figure 5 shows clearly that the majority of Jews deported from Dresden to Theresienstadt were born within the borders of the German Empire; much smaller percentages were born within the Austro-Hungarian and Tsarist Empires; and a few were born elsewhere. The implication from these facts is that the withdrawal of citizenship in 1941 must have had an impact upon the 303 individuals from Dresden who were born within the German empire.

However, although the majority were born in the German Empire and were arbitrarily stripped of their German citizenship, none died within the borders of Germany as they existed in 1938. Figure 6 gives an overview of their place of death in numbers and this links back to Table 2 which gives the numbers who perished in each place of death per deportation. The overwhelming majority perished in Theresienstadt, but a significant number were also murdered in Auschwitz-Birkenau.

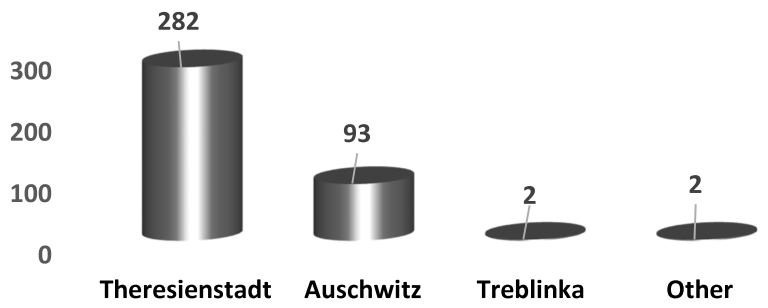

Figure 6. Places of death. 
The distribution of numbers in Figure 6 suggest that the group of deportees from Dresden did not fit the pattern of the other inmates of Theresienstadt. Yad Vashem's information states that whilst 33,000 individuals died in Theresienstadt, 85,000 were deported elsewhere to their deaths ${ }^{42}$. Gruner ${ }^{43}$, Gryglewski ${ }^{44}$ and Murmelstein ${ }^{45}$ all maintain that Theresienstadt functioned as a transit station en route to the death camps in the east. Murmelstein states that this was because Theresienstadt was overcrowded which, together with poor food and bad hygiene, resulted in epidemics. The solution to this, forced on the Jewish administration by the SS, was to deport selected inmates eastwards. Unlike the majority of those incarcerated at Theresienstadt, of the Dresden deportees, $74 \%$ of those who perished, died in Theresienstadt.

However, if the length of time each deportee spent in Theresienstadt before they died or were sent east is considered, then another fact emerges.

Table 6. Average time (months) incarcerated in Theresienstadt.

\begin{tabular}{lcc}
\hline Deportation Ref. & \multicolumn{2}{c}{ Average time (months) incarcerated in Theresienstadt } \\
\hline V/1 & Before death at Theresienstadt & Before deportation to Auschwitz-Birkenau \\
V/2 & 6.5 & 20 \\
V/3 & 6.3 & 19 \\
V/4 & 9.6 & 19 \\
V/5 & 7.6 & 19.5 \\
V/6 & 4.6 & 23 \\
V/7 & 5.4 & 18 \\
V/8 & 4.3 & 22.9 \\
V/9 & 4.6 & 15.5 \\
V/10 & 4.4 & 14 \\
\hline
\end{tabular}

Table 6 shows that for every deportation, the length of time spent in the Theresienstadt ghetto was considerably lower for those who died in Theresienstadt than for those who were sent to Auschwitz-Birkenau.

When average age at entry to Theresienstadt is also considered (Table 7), then those that died there were older on average than those who were deported to Auschwitz-Birkenau.

Table 7. Average age (years) on entry to Theresienstadt.

\begin{tabular}{ccc}
\hline Deportation Ref. & \multicolumn{2}{c}{ Average age (years) on entry to Theresienstadt } \\
\hline V/1 & For those who died at Theresienstadt & For those deported to Auschwitz-Birkenau \\
V/2 & 73.3 & 62.6 \\
V/3 & 76 & 71.5 \\
V/4 & 63 & 54 \\
V/5 & 73.5 & 65.8 \\
V/6 & 73.6 & 66.5 \\
V/7 & 73.7 & 64.2 \\
V/8 & 67.3 & 54 \\
V/9 & 74.4 & 49.3 \\
V/10 & 76.4 & 39.8 \\
\hline
\end{tabular}

Given the shortage of food, the poor hygiene conditions and the epidemics, it is no surprise that the older individuals were less able to withstand the conditions in Theresienstadt. It would also appear that as the younger deportees weakened, they were no longer useful and were sent east to the extermination camps to make space for more recent arrivals, thus confirming what was intended at the Wannsee Conference death by outright murder or death by work exhaustion ${ }^{46}$. This would suggest that Gryglewski (1998) is accurate in stating that for some, Theresienstadt was a place of death, whilst for others it was a transit stop on the way to death ${ }^{47}$.

In Hirschberg's eye-witness testimony of 1944-1945, he writes that 22,000 inmates of Theresienstadt were sent east between May and October $1944^{48}$. This preceded the closure of Auschwitz-Birkenau on 02 November $1944^{49}$ and this included 52 victims from Dresden. 


\section{Occupations and Houses for Jews (Judenhäuser)}

The last two categories to consider from the deportation transcripts are the occupations and the final addresses of the deportees in Dresden prior to their transportation to Theresienstadt, to determine if either or both of these categories shed any light on the socio-economic status of the Jews deported.

The process of isolating the Jewish citizens of Germany in Dresden from 1933 onwards when the Nazis came to power is well documented ${ }^{50}$. Key features were: the boycott of Jewish shops and businesses from 01 April 1933, the dismissal of Jews from the civil service, universities and cultural institutions between April and November 1933, the Nürnberg race laws of 1935 which took away the right of Jews to vote, the Aryanisation of Jewish businesses especially in 1938-1939, and the confiscation of Jewish buildings and the basics for existence in March $1938^{51}$. This increasing social and economic isolation is the background to the following discussion about the occupations listed on the deportation sheets. The most prevalent occupations are shown in the Table 8 below.

Table 8. Principal Occupations of Deportees from Dresden.

\begin{tabular}{ll}
\hline Occupation & Number \\
\hline Businessman & 60 \\
Care worker & 5 \\
Dealer & 5 \\
Sales & 11 \\
\hline
\end{tabular}

It is impossible to draw any firm conclusions about social standing from the information in Table 8, partly because the restrictions on the economic life of the Jews imposed by the Nazis were so onerous and because the terms 'businessman' and 'sales' are very vague. Pieper's (2014) comment that it is impossible to make any statement about social classification from occupational data appears to be supported by the information recorded on the Dresden deportation lists ${ }^{52}$ which is just too vague to be useful for these purposes.

The next step in the isolation of the Jewish population was the forced resettling of the individuals from their family homes and into specific houses, the so-called Judenhäuser or houses for Jews. Goldenbogen (1996) ${ }^{53}$ uses the term 'ghettoisation' to describe this indignity. This process began in Dresden in the autumn of 1939. There were 37 houses set aside for Jews, but only 32 were ever used ${ }^{54}$. A list giving the 'Jewish' houses is given in the cutting below (Figure 7). The caption reads: "Clean break between the Jews and Aryans in Dresden to be carried out by 01 April 1940 at the latest." 


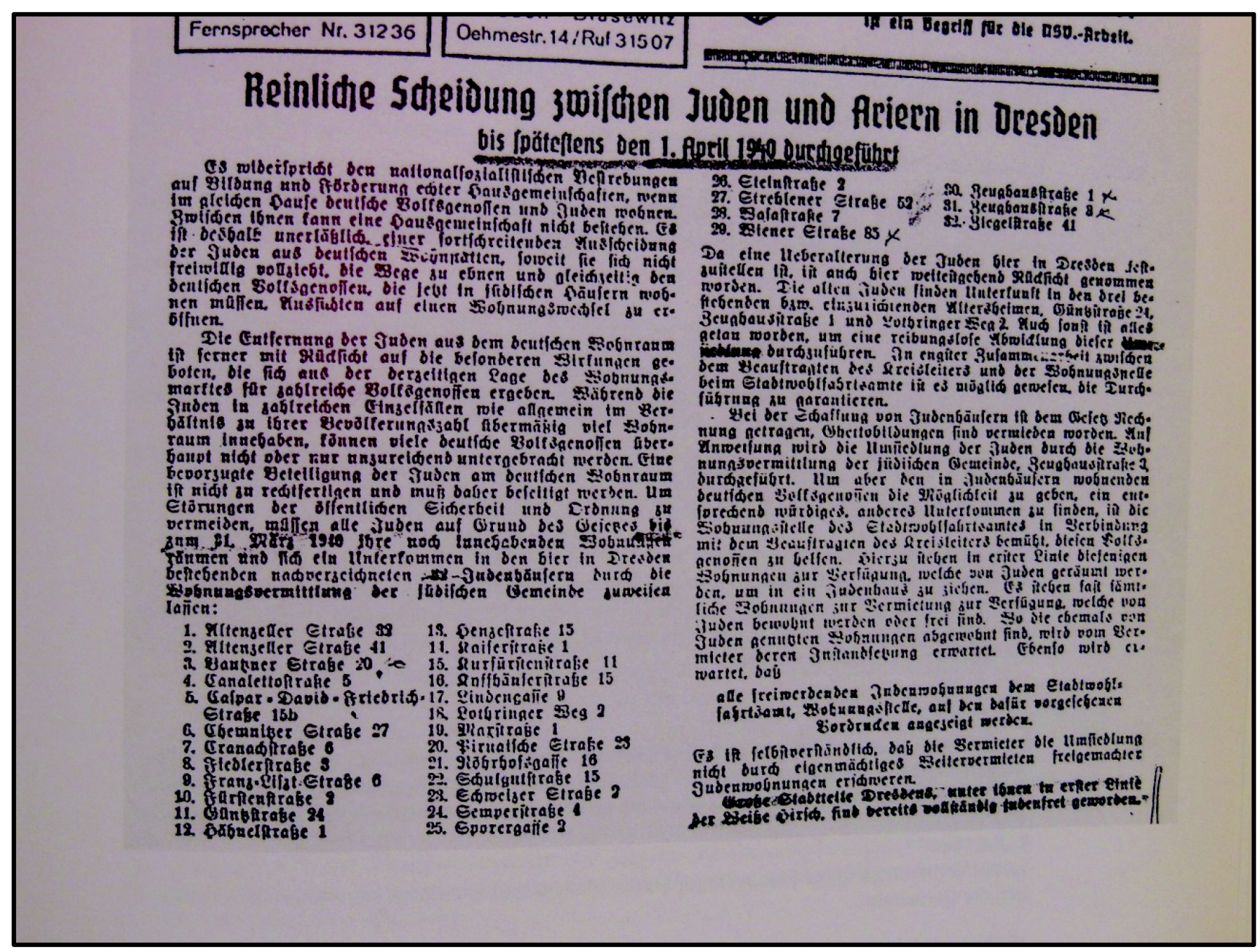

Figure 7. Newspaper cutting on the resettlement of Jews in Dresden ${ }^{3}$.

All 32 houses are listed here. A summary table giving the percentage of those deported from Dresden to Theresienstadt who lived in 'Jewish' houses is shown below (Table 9).

Table 9 Percentage of deportees living in "Houses for Jews" prior to deportation.

Number in 'Jewish' houses Number not in 'Jewish' houses Number in addresses outside of Dresden Addresses illegible

257

$59 \%$
115

$26 \%$
61

$14 \%$
$1 \%$

Although the figure of 59\% in Jewish houses seems low given the fervour with which the Nazis in Dresden persecuted the Jewish inhabitants there, it should be noted that there were 61 individuals who did not live in Dresden, but lived in the surrounding area, and there were 37 Jews in mixed marriages who did not need to live in the houses set aside for Jews. When they are discounted, then the percentage of those living in 'Jewish' houses rises to $76 \%$. This relatively high percentage means that Pieper's (2014) comment regarding the impossibility of deducing social status from the occupational data on the deportation lists is also true for addresses as most deportees lived in the 'Jewish' houses where the only entry criterion was that the person was Jewish, and socio-economic status was not relevant. 
This transcription of Dresden deportations lists shows that the ITS archive material can be used to provide social and historical insights at the group level by analysing the deportations in terms of survival rates by age, length of time incarcerated and gender. It is also very useful for supplying valid information on places of birth and places of death. However, taken in isolation, the deportation lists themselves cannot provide research insights into the family history of the individuals persecuted by the Nazis.

\section{Conclusion}

The purpose of this study was to focus on the deportation of 435 predominantly aged Jews from their homes in Dresden to the Theresienstadt concentration camp and investigate if any new knowledge about the fate of those Jewish people under the Nazi regime emerges from such a study. The reason why this is an important question is that the ITS has only been accessible to the public since 2007, albeit in a limited way, thus giving researchers, family historians and individuals access to the millions of documents contained in its archives.

The main findings of this study arising out of the analysis of the transcribed deportation lists covering 435 deportees are as follows:

1. The most significant finding is the extraordinarily high death rate at Theresienstadt itself of the Dresden group compared to other inmates at Theresienstadt. Of those Dresden Jews that perished, $74 \%$ were murdered at Theresienstadt and $26 \%$ at other death camps. This contrasts with the Yad Vashem figures, which show that of the 118,000 individuals who were murdered, only $28 \%$ perished in Theresienstadt whilst $72 \%$ perished elsewhere ${ }^{55}$.

2. The second important finding is the fact that, of the total number of survivors, proportionately more women survived than men. This is different from the findings elsewhere that more men tended to survive than women because the men were physically better able to endure the rigours of slave labour and camp life ${ }^{56}$. The reason for this may be the fact that the deportees were mainly elderly people who were not required to work, but this warrants further research.

3. The third important finding is that male and female survivors were on average four to six years younger than those that perished which is not unexpected.

The general findings that reflect Nazi policies are as follows:

1. The deportation of Jews from Dresden to Theresienstadt from July 1942 until the end of 1943 was in accordance with the criteria established at the Wannsee Conference of January 1942. The head of the Gestapo, Heinrich Müller, changed this policy on 18 December $1943^{57}$ and this change was reflected in the series of V/10 deportations from Dresden in 1944, as these contained only Jews whose marriage to a non-Jew had ended either because their partner died or their partner divorced them.

2. The second important finding is the fact that the Nazi desire to make Germany 'free of Jews' was such a fundamental part of their ideology that individual V/10 deportations from Dresden continued throughout 1944, and a deportation V/11 was planned for February 1945, even though the war was lost.

The value of the approach of using deportation lists as springboard for research into the group of elderly people deported from Dresden to Theresienstadt between 1942 and 1944 is best summed up in a document issued by ITS itself which states:

"With the passage of time, the deportation lists which the Prussian sense of order and lucky accident have preserved, appear to be assigned a new importance: from an aid to the search for missing persons, they have developed into an instrument for clarification and warning ${ }^{58 .}$

The evidence presented and highlighted in this conclusion, shows that an analysis of the deportation of elderly Jews from Dresden to Theresienstadt reveals features which would not have been so evident if the lists had not existed. This study also shows that worthwhile results emerge if lists, such as deportations lists, are analysed at group level. They also show that, contrary to the illusion created cynically and deliberately by the Nazis, Theresienstadt was by no means a spa town for elderly Jews, but simply another cog in the German death machine as it rampaged through the Jewish communities of Europe.

Two areas of further study emerge from this project and these are the surprising findings:

- The differences in gender survival rates between women and men in the group from Dresden compared with the survival rates between women and men in other camps.

- And the fact that so many of this group perished in Theresienstadt in comparison with others who were deported there. 
It would be useful to compare these findings with the comparative rates of survival between women and men, and the rates of death in Theresienstadt with groups of elderly Jews from other German cities which had smaller, the same and larger populations of Jews who were deported to Theresienstadt. This would show if Dresden was unique in these characteristics.

\section{References}

1. Yad Vashem. Theresienstadt. https://www.yadvashem.org/odot_pdf/Microsoft\% 20Word\%20-\%205875.pdf: accessed 04 December 2020. P.2.

2. Belgium, France, the Federal Republic of Germany, Israel, Italy, Luxembourg, Netherlands, UK and the US. Poland and Greece.

3. Jah, Akim, Kühling, Gerd. (2016) Fundstücke 4: Die Deportation der Juden aus Deutschland und ihre verdrängte Geschichte nach 1945/The deportation of Jews from Germany and their suppressed history after 1945. Göttingen: Wallstein Verlag. p. 12

4. Longerich, Peter. (1994) Die Wannsee-Konferenz vom 20. Januar 1942 Planung und Beginn des Genozids an den europäischen Juden The Wannsee Conference of 20 January 1942. The planning and commencement of the genocide of European Jewry. https://scholar.google.de: accessed 08 September 2020. p. 11. Murmelstein Benjamin. (2014) THERESIENSTADT Eichmann's Vorzeige-Ghetto/Theresienstadt Eichmann's model ghetto. Wien: Czernin Verlag. p. 127.

5. The United States Holocaust Memorial Museum (USHMM). Theresienstadt. https:// encyclopedia.ushmm.org/content/en/article/theresienstadt-red-cross-visit: accessed 25 October $<y r>2020$.

6. Longerich, op. cit. p. 11 .

7. Schnabel, Marie. Eyewitness testimony, Doc 1656, P.Ill.h. (Theresienstadt) No. 1189 translated from the German by Des Maguire on behalf of the Wiener Library. p. 4

8. The United States Holocaust Memorial Museum (USHMM). Theresienstadt. https:// encyclopedia.ushmm.org/content/en/article/theresienstadt-red-cross-visit: accessed 25 October $<y r>2020$.

9. Yad Vashem, op. cit. p.2

10. Roseman, Mark. (2002) The Wannsee conference and the final solution: a reconsidera tion. New York: Picador. p. 156

11. Gottwaldt, Alfred, Schulle, Diana. (2007), Die Judendeportationen' aus dem Deutschen Reich 1941-1945. The Jewish deportation out the German Reich, 19411945. Wiesbaden: Marixverlag. p. 267

12. Gottwaldt, Alfred, Schulle, Diana, op.cit. p.364.

13. Eschwege, Helmut. (1995) Die jüdische Gemeinde in Dresden 1945 bis 1953/The Jewish Community in Dresden 1945 to 1953. In Dresdner Hefte. 28(4). pp. 62-72. https://digital.slub-dresden.de/werkansicht/dlf/72137/1/: accessed 08 September 2020. p. 62.

14. Longerich, op. cit. p. 4.

15. Held, Steffen. (2008) Die Leipziger Stadtverwaltung und die Deportation der Juden im NSStaat, Leipzig/The city administration in Leipzig and the deportation of Jews in the Nazi state. Stadtgeschichtliches Museum. http://www.qucosa.de/fileadmin/data/ qucosa/documents/7155/Deportationen_Leipzig.pdf: accessed 08 September 2020. p. 5 .

16. Urban, Susanne. (2013) 'Deportationen als Matrix Nazi-Deutschlands/Deportations as a matrix of Nazi Germany.' In: Lilienthal, Marion, Stadtler, Karl-Heinz, VölckerJanssen, Wilhelm, eds. (2013) "Auf Omas Geburtstag fahren wir nach P.": die gewaltsame Verschleppung von Juden aus Waldeck-Frankenberg 1941/42: Kassel - Riga Sobibor/Majdanek, Theresienstadt/On Grandma's birthday, we travel to $P$. The violent abduction of the Jews from Waldeck-Frankenberg 1941/42. Korbach: WolfgangBonhage-Museum. pp. 15-34.

17. Turner, Henry Ashby Jr. (1999) Victor Klemperer's Holocaust. German Studies Review. 22(3). pp. 385-395. https;//www.jstor.org/stable/1432266: accessed 08 September 2020.

18. Murmelstein, Benjamin. (2014) THERESIENSTADT Eichmann's Vorzeige-Ghetto/ Theresienstadt Eichmann's model ghetto. Wien: Czernin Verlag. p. 213.

19. Murmelstein, op. cit. p. 213

20. Bergmann, Werner. (2016) Geschichte des Antisemitismus/History of Anti-semitism. 5th ed. Munich: C. H. Beck.

21. Schmeitzner, Mike. (2016) Tödlicher Hass: Antisemitismus und Judenverfolgung in Dresden 1933-1945./Deadly hate: Anti-Semitism and the persecuting of Jews in Dresden 1933-1945. Medaon, 10, 19. pp.1-29. http://www.medaon.de/pdf/ medaon_19_Schmeitzner.pdf accessed: 08 September 2020. p. 26.

22. Yad Vashem, op. cit. p.2.

23. Frischmann, Ilse. (1993) Das war die absolute Ausgrenzung!/That was total exclusion. Dresdner Hefte, 35 pp. 27-33. https://digital.slub-dresden.de/werkansicht/dlf/ 72051/1/0/: accessed 08 September 2020. p. 29.
24. Mayer, Heinz. Eyewitness testimony, Doc 1656, P.Il.a. No. 543, translated from the German by Des Maguire on behalf of the Wiener Library.

25. Frahm, Paula. Eyewitness testimony, Doc 1656, P.Ill.h. (Theresienstadt) No. 516, translated from the German by Des Maguire on behalf of the Wiener Library. p. 2.

26. Anonymous. Eyewitness testimony, Doc 1656, P.Ill.h. (Theresienstadt) No. 581 , translated from the German by Des Maguire on behalf of the Wiener Library.

27. Jah, op. cit. p. 15

28. Hirschberg, Hans Walter. Eyewitness testimony, Doc 1656, P.Ill.h. No. 712 (Theresienstadt), translated from the German by Des Maguire on behalf of the Wiener Library.

29. Baumel, Judith Tydor. (1998) Double Jeopardy Gender and the Holocaust. London: Vallentine Mitchell \& Co. p. 235

30. Hajkova, Anna. (2016) Women as citizens in the Theresienstadt prisoner community. SciencesPo. https://www.sciencespo.fr/mass-violence-war-massacre-resistance: accessed 08 September 2020. p. 1.

31. Longerich, op. cit. p. 9

32. Goldenbogen, Nora. (1996) Nationalsozialistiche Juden Verfolgung in Dresden seit 1938 - ein Überblick/An overview of the persecution of the Jews in Dresden under National Socialism from 1938. Dresdner Hefte. 45 pp. 76-84. https://digital.slubdresden.de/werkansicht/dlf/72154/1/: accessed 08 September 2020. p. 82.

33. Gryglewski, Marcus. (1998) 'The face of National Socialist persecution of the Jews in Dresden 1933-1945'. In: Haase, Norbert, Jersch-Wenzel, Stefi, Simon, Hermann (HG). Bearbeitet von Marcus Gryglewski. (1998) Die Erinnerung hat ein Gesicht/ Rememberance has a face. Leipzig: Gustav Kiepenheuer Verlag GmbH. P. 138.

34. Goldenbogen, op. cit. p. 82.

35. Gestapo Deportation List, V/9, 11 August 1942, Dresden to Theresienstadt. ITS, Search All Archive Units, Document Id: 11197478_0_1, 11197479_0_1.

36. Hajkova, op. cit. p. 1. p. 5.

37. Holocaust.Cz. HIRSCHEL, Kurt. https://www.holocaust.cz/databaze-obeti/obet/ 15912-kurt-hirschel/: accessed 15 May 2018.

38. Hirschberg, op. cit. p. 3.

39. Gerlach, Christian. (1998) The Wannsee Conference, the Fate of the German Jews, and Hitler's Decision in in Principle to Exterminate All European Jews. The Journal of Modern History. http://www.journals.uchicago.edu/t-and-c: accessed 05 December 2017. p. 802

40. Schmeitzner, op. cit. p. 26

41. Bergmann, Werner. (2016) Geschichte des Antisemitismus/History of Anti-semitism 5th ed. Munich: C. H. Beck

42. Yad Vashem. Theresienstadt. http://www.yadvashem.org/holocaust/about/ghettos/ theresienstadt.html: accessed 08 September <yr $>2020$

43. Gruner, Wolf. (2004) 'From the collective isolation to the deportation of Jews from Germany (1939 - 1945). New perspectives and documents'. In: Kundrus, Birthe, Mayer, Beate. eds. The deportation of Jews from Germany: plans, practices and reactions, 1938-1945. Göttlingen: Wallstein. p.106.

44. Gryglewski, op. cit. p. 131.

45. Murmelstein, op. cit. p. 78.

46. Longerich, Peter, op. cit. p. 8

47. Gryglewski, op.cit. p. 131

48. Hirschberg, op.cit.

49. Murmelstein, op. cit. p. 178

50. Diamant, Adolf. (1973) Chronik der Juden in Dresden. Von den ersten Juden bis zur Blüte der Gemeinde und deren Ausrottung/Chronicle of the Jews in Dresden from the first Jews, through the blossoming of the community to their extermination. Darmstadt: Agora.

51. Schmeitzner, op. cit. pp. 5-20.

52. Pieper, Christine. (2014) Juden in Sachsen 1933 bis 1945: Ein defizitäres Forschungsfeld/Jews in Saxony 1933 to1945: a neglected research area. MEDAON 15/2014. http://www.medaon.de/pdf/MEDAON_15_Pieper.pdf: accessed 08 September 2020.

53. Goldenbogen, op. cit. p. 78

54. Goldenbogen, op. cit. p. 79.

55. Yad Vashem. Theresienstadt. http://www.yadvashem.org/holocaust/about/ghettos/ theresienstadt.html: accessed 08 September <yr>2020. 
56. Baumel, Judith Tydor. (1998) Double Jeopardy Gender and the Holocaust. London: Vallentine Mitchell \& Co. p. 235.
57. Murmelstein, op. cit. p. 213

58. Jah, op. cit. p. 17

\section{ABOUT THE AUTHOR}

The author is a Glasgow born Scot who was educated at universities in both Scotland and England. He has a M.Sc. in Genealogy, Heraldry and Palaeography from the University of Strathclyde. He spent most of his working life developing software for large UK and US companies, and today he is an enthusiastic, volunteer translator (German into English) for the Wiener Holocaust Library in London. 